\title{
PENDAYAGUNAAN POTENSI EKONOMI DESA PATERONGAN KECAMATAN GALIS MELALUI KKN MAHASISWA STAIDHI TAHUN 2020
}

\author{
Mashudi, Didik Suparyanto, Bustomi Arisandi \\ STAI Darul Hikmah Bangkalan \\ Mashudi.smart@darul-hikmah.com, didik@darul-hikmah.com, \\ abindri@gmail.com
}

\begin{abstract}
ABSTRAK
Pembangunan masyarakat adalah merupakan tanggung jawab bersama. Setiap individu, kelompok, institusi pemerintah maupun swasta dapat saling bersinergi untuk melaksanakan tanggung jawab pembangunan tersebut. Oleh karena itu, pembangunan masyarakat harus dilakukan secara berkelanjutan dengan perencanaan program yang terstruktur dan melibatkan banyak pihak sesuai dengan wewenang dan kompetensinya. Guna mewujudkan tangggung jawab pembangunan dan semangat ingin mengabdi kepada masyarakat, Sekolah Tinggi Agama Islam Darul Hikmah (STAIDHI) melaksanakan program pengabdian kepada masyarakat yang dikemas dalam Kuliah Kerja Nyata (KKN) bersinergi dengan pemerintahan desa Paterongan kecamatan Galis kabupaten Bangkalan. Kegiatan KKN STAIDHI Tahun 2020 ini mengusung tema "pendayagunaan potensi ekonomi desa Paterongan kecamatan Galis menuju kemandirian ekonomi". Pendayagunaan potensi desa Paterongan Kecamatan Galis ini dituangkan dalam 5 program, yaitu; mengadakan pelatihan pembuatan kripik pepaya dan kripik daun bayam, gerakan pemanfaatan pupuk kandang difermentasi untuk kesuburan lahan, pembelajaran pertanian porang untuk pemanfaatan lahan nganggur, mengembangkan jejaring pemasaran melalui ide dan implementasi manajemen bauran pemasaran, merumuskan pengurusan hak paten dari produk-produk yang telah dihasilkan.Berdasarkan hasil evaluasi yang telah dilakukan, masyarakat warga desa Paterongan kecamatan Galis kabupaten Bangkalan merasakan sangat bermanfaat dengan adanya program pengabdian ini.
\end{abstract}

Kata Kunci; Pendayagunaan, potensi ekonomi desa Paterongan kecamatan Galis. 


\section{A. LATAR BELAKANG}

Permasalahan ekonomi di pedesaan merupakan masalah sosial yang membutuhkan solusi dan pemikiran semua pihak. Dari data hasil sensus ekonomi terakhir tahun 2020, diketahui bahwa mayoritas masyarakat pedesaan di semua kecamatan kabupaten Bangkalan termasuk masyarakat pra sejahtera, tak terkecuali juga mayoritas masyarakat di Desa Paterongan Kecamatan Galis Kabupaten Bangkalan.

Kenyataan ini ditambah lagi dengan musibah pandemi covid-19 yang melanda Indonesia. Kabupaten Bangkalan yang juga sempat menduduki predikat zona merah dalam penyebaran wabah tersebut, terpaksa harus melaksanakan Pembatasan Sosial Berskala Besar (PSBB). Sehingga semua warga Bangkalan mencari ide kreatif agar tetap dapat memenuhi kebutuhan hidupnya tanpa membahayakan dirinya maupun orang lain dari ancaman penyebaran wabah covid-19 tersebut.

Meskipun saat ini Kabupaten Bangkalan telah berhasil keluar dari dari zona merah dan siap menjalankan kehidupan new normal, akan tetapi tidak mudah untuk mengembalikan kerugian-kerugian dan peluang ekonomi yang telah hilang karena pelaksanaan PSBB tersebut. Semua elemen masyarakat Bangkalan harus saling bersinergi untuk membangun kembali sendi perekonomian, dimulai dari masyarakat pedesaan yang secara potensi sumber daya alamnya melimpah. Mendayagunakan segala potensi yang ada di pedesaan merupakan pilihan yang prospektif dari pada harus menunggu dan menggantungkan diri kepada bantuan pemerintah yang masih besar keperluannya.

Oleh karena itu, Sekolah Tinggi Agama Islam Darul Hikmah (STAIDHI) Bangkalan bertekad turut serta membangun ekonomi pedesaan, yaitu di Desa Paterongan Kecamatan Galis Kabupaten 
Bangkalan. Tekad tersebut dilaksanakan melalui kegiatan Kuliah Kerja Nyata (KKN) STAIDHI Tahun 2020, dengan tema "Membangun Desa di era New Normal dengan Meningkatkan Nilai Pendidikan Dan Keagamaan, serta Ekonomi Kreatif”. Melalui kegiatan KKN ini, mahasiswa STAI Darul Hikmah bersinergi dengan pemerintahan desa Paterongan Kecamatan Galis dalam mengolah potensi ekonomi desa tersebut.

Hal ini senada dengan apa yang menjadi cita-cita dan semangat Kepala Desa (Kades) Paterongan Kecamatan Galis Bangkalan. Bapak Ach Z. Heryyanto (Kades Paterongan) memiliki visi membangun Desa Paterongan yang mandiri di era new normal pasca zona merah penyebaran pandemi covid-19 ini. Sehingga sinergitas antara semangat Desa dengan tekad kampus STAIDHI untuk mengabdi dalam pembangunan masyarakat pedesaan yang mandiri, menjadi modal utama kegiatan pendayagunaan potensi ekonomi Desa Paterongan Kecamatan Galis Kabupaten Bangkalan.

\section{B. KEADAAN DAN PERMASALAHAN DESA PATERONGAN KECAMATAN GALIS}

Desa Paterongan adalah salah satu desa yang ada di Kecamatan Galis Kabupaten Bangkalan, dengan rata rata ketinggian 45 - 50 mpal. Desa Paterongan memiliki 6 Dusun memanjang dari barat sampai timur dan melebar dari utara ke selatan. Luas wilayah 461 ha, dengan batas batas wilayah yaitu sebelah utara ada desa Daleman, arah selatan Kajuanak, arah barat berbatasan dengan desa Galis dan arah timur terdapat Desa Lombang. Pola permukiman terdiri dari bangunan permanen, semi permanen dan non permanen. Desa Paterongan sebelah utara nya terdapat jalan raya dari arah bangkalan menuju Sampang, dan 
dari pasar kecamatan berjarak $\pm 2 \mathrm{~km}$. Adapun jumlah bangunan yang ada di desa Paterongan dapat dirinci sebagai berikut :
a. \pm 196 bangunan rumah permanen
b. \pm 71 bangunan rumah semi permanen
c. \pm 45 bangunan rumah non permanen

Seluruh masyarakat Desa Paterongan beragama Islam. Desa ini memiliki tiga Madrasah Diniyah dan lima masjid masing-masing berada di dusun Tengginah Laok, Tokoneng, Kolla, Rompeng, Mur Gunong. Keberadaan lima masjid ini untuk memenuhi sarana dan prasarana tempat beribadah warga desa Paterongan yang memiliki jarak sangat dekat.

Masyarakat desa Paterongan memiliki beragam kegiatan keagamaan di masing-masing dusunnya, diantara lain :

1. Yasinan rutin tiap minggu di malam Jumat, yasinan ini diikuti oleh bapak bapak dengan giliran per dusun di berbagai rumah.

2. Rutinitas Sholawat Diba'iy tiap malam Kamis yang diikuti oleh pemuda dan remaja tiap masjid per dusun.

3. Istighasah bersama tiap minggu di malam Rabu yang diikuti remaja masjid Paterongan dusun Tengginah Laok.

Dengan demikian, secara sosial keagamaan masyarakat desa Paterongan memiliki ukhuwah yang sangat kuat. Mereka tidak terpisahkan sekat unsur-unsur individu karena tiap minggu mereka bisa saling berjumpa memupuk persaudaraan. Acara-acara seperti Yasinan, Diba'iy, serta Istighasah tidak hanya menjadi ajang kepentingan keagamaan tetapi juga menjadi momen silaturrahim membahas permasalahan perkembangan sosial ekonomi, seperti masalah kebutuhan warga, perkembangan kerajinan pandai besi, serta pemanfaatan lahan pertanian. 
Penggunaan lahan di desa Paterongan masih didominani sektor pertanian yang terdiri dari persawahan dan perkebunan. Lahan pertanian di desa Paterongan hanya diisi dengan benih kacang dan jagung yang penanamannya hanya dua kali dalam setahun karena petani desa Paterongan masih menggantungkan terhadap curah hujan. Oleh karena itu, penduduk desa Paterongan tidak terfokus pada kegiatan pertanian saja, melainkan banyak mengisi waktunya dengan kreatifitas lainnya, antara lain seperti pandai besi. Oleh karena itu, bisa dikatakan bahwa kehidupan perekonomian di desa Paterongan dominan menggantungkan diri pada pendapatan hasil pandai besi.

Kegiatan sebagai pandai besi ini dapat dikatakan menjadi pekerjaan utama penduduk desa Paterongan. Hampir 60 persen penduduk di situ melakukan pekerjaan ini. Pekerjaan pandai besi ini biasanya dilakukan pada malam hari. Sedangkan pada siang harinya mereka sebagian ke kebun untuk merawat tanaman perkebunan jika pada musim hujan.

Pertanian yang mereka lakukan memang hanya mengandalkan turunnya air hujan. Hanya sebagian yang mengandalkan pertanian seperti jagung, kacang dan peternakan ayam serta ada beberapa keluarga yang berternak sapi. Pertanian yang mereka lakukan juga masih tradisional seperti yang dilakukan secara turun-temurun, mulai dari penanaman, pemupukan, hingga panen. Semua dilakukan dengan kualifikasi keterampilan dan teknologi yang sederhana.

Usaha lain penduduk desa Paterongan ada juga yang berjualan, baik dikampung sendiri atau keluar daerah Bangkalan. Mereka ada yang berdagang makanan hasil pertanian, hingga barang-barang lainnya seperti hasil kerajinan pandai besi seperti pisau, celurit, cangkul, dan semua kebutuhan pertanian lainnya, hingga kebutuhan rumah tangga. 
Mereka juga melayani pemesanan bagi masyarakat dari luar desa Paterongan yang belum memiliki akses langsung ke para pandai besi di desa Paterongan. Mereka mendapatkan keuntungan dari selisih harga yang mereka dapatkan dari para pengrajin dengan harga jual yang ada di pasaran. Hubungan kemitraan antara pedagang dengan pengrajin itu berjalan saling menguntungkan karena para pengrajin juga membutuhkan pemasaran hasil kerajinannya.

Namun sejak covid-19 melanda, semua kegiatan yang berkaitan dengan perdagangan ke luar daerah Paterongan mengalami kemacetan. Adanya pembatasan sosial Kabupaten Bangkalan juga berdampak pada menurunnya pendapatan mereka dari sektor ini. Hal itu juga berdampak pada kegiatan produksinya di desa tersebut. Para pandai besi juga menghadapi kendala dalam memasarkan hasil kerajinannya. Para pengrajin pandai besi hanya beroperasi seadanya jika ada pesanan, yang penting tetap bisa memenuhi kebutuhan hidup sehari-harinya dengan mengatur keuangannya secara ketat.

Menyaksikan kondisi perekonomian masyarakatnya yang demikian, Bapak Kades Paterongan (Ach. Z. Herryanto) memutar otak, mencari cara dan jaringan kemitraan yang dapat diajak kerja sama untuk membangun desa Paterongan menjadi desa yang mandiri, terutama dalam ketahanan pangan. Ketersediaan lahan perkebunan yang lumayan luas di desa tersebut ingin difungsikan maksimal. Demikian juga dengan hasil kerajinan mayoritas penduduknya sebagai pandai besi, juga diharapkan dapat kembali memberikan pendapatan yang layak untuk memenuhi kebutuhan hidup warganya. 


\section{POTENSI UNGgulaN NILAI EKONOMIS DAN USULAN SOLUSI PENDAYAGUNAAN}

Berdasarkan hasil pengamatan terhadap kondisi sosial ekonomi penduduk desa Paterongan Kecamatan Galis Kabupaten Bangkalan, maka diidentifikasi beberapa potensi unggulan nilai ekonomis kaitannya dengan pendayagunaan yang akan dilakukan. Potensi-potensi tersebut antara lain adalah:

1. Home industri kerajinan pandai besi oleh sebagian besar penduduk desa Paterongan Kecamatan Galis sangat produktif.

2. Potensi pasar hasil kerajinan pandai besi tersebut sangat dibutuhkan karena tidak banyak daerah di Kabupaten Bangkalan yang menekuni bidang kerajinan tersebut. Bahkan potensi permintaan pasar terbuka lebar dari pasar di luar Kabupaten Bangkalan.

3. Potensi hasil pertanian desa Paterongan Kecamatan Galis Kabupaten Bangkalan juga ada, seperti buah pepaya yang lumayan banyak, sayur-mayur seperti kacang panjang, bayam, dan lain-lain.

4. Telah terbentuknya kelompok ibu-ibu PKK yang dipimpin oleh Ibu Kades sendiri, dan dalam banyak kesempatan mereka mengadakan acara kumpul-kumpul untuk berdiskusi tentang arisan, dan lain-lain.

5. Hasil pupuk kandang petani kambing dan sebagian kecil sapi yang dapat diolah menjadi pupuk bernilai tinggi yang bermanfaat untuk pengolahan lahan yang ada.

6. Potensi lahan perkebunan yang masih tersedia dan dibiarkan tidak produktif tanpa pemanfaatan yang bernilai ekonomis.

Berbagai uraian dari potensi-potensi yang telah diidentifikasi ini, selanjutnya akan diusulkan pendayagunaannya dalam rangka pemberdayaan masyarakat untuk membangun perekonomian desa 
Paterongan yang mandiri. Oleh karena itu, maka terdapat beberapa usulan penyelesaian masalah (solusi) yaitu:

1. Pelatihan pengolahan hasil pertanian (buah pepaya dan sayur bayam) yang melimpah untuk diolah menjadi produk olahan yang lebih memiliki nilai ekonomis, dengan memberdayakan kelompok ibu-ibu PKK yang telah ada.

2. Penggalakan gerakan menanam porang di lahan-lahan nganggur yang selama ini tidak produktif bersinergi dengan Bapak Kades desa Paterongan kecamatan Galis Kabupaten Bangkalan.

3. Program penyuluhan pemasaran produk kerajinan pandai besi beserta produk-produk hasil olahan lainnya, bagi para pengrajin pandai besi dan kelompok ibu PKK dengan memperkenalkan pentingnya hak paten dan pengembangan jaringan pemasaran.

4. Pelatihan pembuatan fermentasi pupuk kandang bersinergi dengan Bapak Kades desa Paterongan Kecamatan Galis Kabupaten Bangkalan.

\section{METODE PELAKSANAAN}

\section{Perumusan Program Pelaksanaan Kegiatan}

Guna merumuskan pelaksanaan kegiatan pengabdian ini, Panitia KKN membagi peserta KKN ke dalam kelompok-kelompok serta menunjuk satu dosen pembimbing untuk tiap kelompoknya. Kemudian masing-masing kelompok dibawah arahan dosen pembimbingnya, menentukan waktu untuk melakukan survey awal dalam rangka menggali informasi awal potensi ekonomi yang ada di desa Paterongan kecamatan Galis kabupaten Bangkalan. Berdasarkan hasil survey awal ke desa Paterongan serta wawancara dengan kepala desa Paterongan, 
maka mahasiswa merumuskan program kerja sesuai dengan potensi yang ada.

Adapun beberapa program pendayagunaan potensi ekonomi oleh kelompok KKN di desa Paterongan adalah sebagai berikut:

Tabel 1.

Pendayagunaan Potensi Ekonomi

\begin{tabular}{|c|c|c|c|}
\hline NO & PROGRAM & SASARAN & KET \\
\hline 1 & $\begin{array}{l}\text { Mendayagunakan potensi } \\
\text { ekonomi yang ada di desa } \\
\text { Paterongan kecamatan Galis } \\
\text { dengan kegiatan: } \\
\text { 1) Mengadakan pelatihan } \\
\text { pembuatan kripik pepaya } \\
\text { dan kripik daun bayam. } \\
\text { 2) Gerakan pemanfaatan } \\
\text { pupuk kandang yang } \\
\text { difermentasi terlebih } \\
\text { dahulu untuk kesuburan } \\
\text { tanah. } \\
\text { 3) Pembelajaran bersama } \\
\text { tentang pertanian porang } \\
\text { untuk memaksimalkan } \\
\text { lahan yang tidak ditanami } \\
\text { oleh warga yang lebih } \\
\text { memilih menjadi pandai } \\
\text { besi. }\end{array}$ & $\begin{array}{l}\text { Kelompok } \\
\text { Ibu PKK } \\
\text { Masyarakat } \\
\text { Paterongan } \\
\text { Masyarakat } \\
\text { Paterongan }\end{array}$ & $\begin{array}{l}\text { Bertujuan } \\
\text { untuk } \\
\text { memaksimal } \\
\text { kan nilai } \\
\text { ekonomi dari } \\
\text { potensi yang } \\
\text { ada untuk } \\
\text { mewujudkan } \\
\text { tujuan desa } \\
\text { mandiri. }\end{array}$ \\
\hline 2 & $\begin{array}{l}\text { Meningkatkan jejaring } \\
\text { pemasaran produk hasil } \\
\text { pandai besi yang merupakan } \\
\text { mata pencaharian utama } \\
\text { rakyat desa Paterongan } \\
\text { kecamatan Galis kabupaten } \\
\text { Bangkalan, melalui: } \\
\text { 1) Membantu merumuskan } \\
\text { pemasaran melalui ide dan } \\
\text { implementasi manajemen } \\
\text { bauran pemasaran. } \\
\text { 2) Merumuskan pengurusan } \\
\text { hak paten dari produk- }\end{array}$ & $\begin{array}{l}\text { Pengrajin } \\
\text { pandai besi }\end{array}$ & $\begin{array}{l}\text { Ekspansi } \\
\text { jangkauan } \\
\text { pasar yang } \\
\text { telah berjalan } \\
\text { selama ini, } \\
\text { dengan value } \\
\text { ekonomi } \\
\text { yang lebih } \\
\text { menjamin } \\
\text { hak-hak } \\
\text { produsen. }\end{array}$ \\
\hline
\end{tabular}




\section{Pelaksanaan Program Kegiatan pepaya dan bayam.}

produk yang telah dihasilkan termasuk kripik

Dalam pelaksanaan program kegiatan Kuliah Kerja Nyata (KKN) di Desa Paterongan tahun 2020 ini bertemakan "Membangun Desa di era New Normal dengan Meningkatkan Nilai Pendidikan Dan Keagamaan, serta Ekonomi Kreatif". Oleh karena itu, bidang ekonomi yang menjadi fokus programnya adalah pendayagunaan potensi ekonomi yang ada di desa Paterongan kecamatan Galis kabupaten Bangkalan. Pelaksanaan program tersebut sebagai bentuk pengabdian kepada masyarakat.

Adapun pelaksanaan program pengabdian masyaakat yang telah disusun sesuai dengan perencanaan awal adalah sebagai berikut:

\section{a. Mengadakan Pelatihan pembuatan olahan kripik dari buah pepaya dan daun bayam.}

Nama Program : Pelatihan pembuatan olahan buah pepaya dan daun bayam.

Penanggungjawab : M,jakfar Sodiq,Ali Imron,Siti Suhana.

Waktu Pelaksanaan : Minggu ketiga (Ahad : 13.00 s/d 16.00).

Tempat : Kediaman Bapak Rosyidi, di Dusun Tengginah Laok

Peserta $\quad$ : Ibu PKK dan Warga Tengginah Laok

Tujuan dan Manfaat: Mengetahui cara pembuatan kripik pepaya dan kripik bayam.

Meningkatkan value ekonomi buah pepaya dan bayam.

Memberi saran altenatif pendayagunaan potensi ekonomi di desa Paterongan kecamatan Galis kabupaten Bangkalan. 
Hasil dan Evaluasi : Untuk program ini, animo masyarakat dusun

Tengginah Laok sangat luar biasa. Menurut aparat desa (Bapak Rosyidi), program ini sangat membantu masyarakat karna kebanyakan warga dusun Tengginah Laok mata pencahariannya sebagai petani, sehingga dengan adanya alternatif pendayagunaan buah pepaya dan daun bayam sebagai kripik sangat menambah nilai ekonomi yang mana biasanya buah pepaya dan daun bayam hanya bisa dimamfaatkan sebagai pelengkap sayuran.

\section{b. Gerakan pemanfaatan pupuk kandang yang difermentasi} terlebih dahulu untuk kesuburan tanah.

Nama Program : Gerakan pendayagunaan pupuk kandang fermentasi

Penanggungjawab : M, Jakfar Sodik dan Abdur Rohman

Waktu pelaksanaan : Setiap hari jam kondisional selama KKN

Tempat

: Area perkebunan penduduk.

Peserta

: Warga Paterongan, Mahasiswa KKN, dan Kades Paterongan

Tujuan dan Manfaat: Mensosialisasikan pendayagunaan potensi alam seperti pupuk kandang hasil fermentasi kepada warga desa Paterongan kecamatan Galis.

Belajar teknik fermentasi pupuk yang kaya manfaat untuk mengembalikan kesuburan tanah di desa Paterongan. 
Hasil dan Evaluasi : Kepala desa Paterongan sangat antusias dengan semangat mahasiswa yang menjadi penggerak dalam program gerakan pendayagunaan pupuk kandang fermentasi ini. Hal ini dapat menjadi solusi di tengahtengah melambungnya harga pupuk saat ini.

\section{c. Pembelajaran pertanian porang untuk memaksimalkan lahan} yang tidak ditanami oleh warga yang lebih memilih menjadi pandai besi.

Nama Program : Pembelajaran pertanian porang.

Penanggungjawab : Ainur Rofik bersinergi dengan kepala desa Paterongan.

Waktu pelaksanaan : Minggu kedua (Ahad, $07.30 \mathrm{~s} / \mathrm{d} 10.00$ ).

Tempat : Area lahan tidak produktif.

Peserta : Warga Paterongan, Mahasiswa KKN, dan Kades Paterongan

Tujuan dan Manfaat: Mensosialisasikan pendayagunaan potensi lahan mangkrak (tidak produktif) warga desa Paterongan kecamatan Galis.

Belajar teknik pertanian porang alternatif pertanian yang prospek mendapatkan pendapatan tinggi, mengingat harga jual buah porang yang mahal.

Hasil dan Evaluasi : Kepala desa Paterongan sangat antusias dengan semangat mahasiswa yang mau bersinergi dalam program pembelajaran pertanian porang. 
d. Membantu merumuskan pemasaran melalui ide dan implementasi manajemen bauran pemasaran.

Nama Program : Pembelajaran pemasaran.

Penanggungjawab : Taufik Umar dan tim.

Waktu pelaksanaan : Minggu pertama (Ahad, $13 . .00 \mathrm{~s} / \mathrm{d}$ 16.00).

Tempat : Kediaman kepala desa Paterongan.

Peserta : Warga Paterongan, Mahasiswa KKN, dan Kades Paterongan

Tujuan dan Manfaat: Belajar implementasi bauran pemasaran untuk membantu memaksimalkan ekspansi pemasaran produk-produk hasil kerajinan warga desa Paterongan kecamatan Galis kabupaten Bangkalan.

Hasil dan Evaluasi : Berdasarkan hasil kajian di lapangan, dijumpai bahwa kegiatan pemasaran produkproduk yang ada belum sesuai dengan prinsip-prinsip dan implementasi manajemen bauran pemasaran.

e. Merumuskan pengurusan hak paten dari produk yang dihasilkan pandai besi, serta produk hasil pelatihan seperti kripik pepaya dan kripik bayam.

Nama Program : Pendampingan pengurusan hak paten.

Penanggungjawab : Samsul Arifin dan tim.

Waktu pelaksanaan : Kondisional (dalam proses komunikasi dengan ketua asosiasi UKM se-Madura).

Tempat : Komunikasi berkelanjutan.

Peserta : - 
Tujuan dan Manfaat: Mengusahakan pengurusan hak paten produk pandai besi dan produk-produk olahan kripik pepaya, kripik bayam warga desa Paterongan kecamatan Galis kabupaten Bangkalan.

Hasil dan Evaluasi : Berdasarkan hasil komunikasi sementara dengan ketua asosiasi UMKM se-Madura, masih menunggu proses dari hasil komunikasi lebih lanjut dengan dinas terkait.

\section{E. KESIMPULAN}

Program KKN STAIDHI 2020 yang berlangsung 1 bulan (tanggal 5 Oktober hingga 5 November 2020) telah berjalan dengan baik dan lancar sesuai sasaran program. Program KKN tersebut mengusung misi pendayagunaan potensi ekonomi desa paterongan kecamatan Galis menuju desa yang mandiri. Dengan program KKN ini mahasiswa mendapat pengalaman belajar yang nyata sekaligus mengabdi kepada masyarakat. Mahasiswa merasakan keterlibatan dalam masyarakat secara langsung mengindentifikasi, menformulasikan, serta memberikan solusi pembangunan desa secara kongkrit dengan interdisipliner.

KKN STAIDHI 2020 ini telah memberikan semangat dan motivasi bagi masyarakat warga desa Paterongan kecamatan Galis kabupaten Bangkalan. Melalui serangkaian program pendayagunaan potensi ekonomi yang telah dilaksanakan, masyarakat mendapatkan berbagai wawasan dan keterampilan antara lain:

1. Pengetahuan dan keterampilan mengolah buah pepaya dan daun bayam menjadi camilan kripik yang memiliki nilai ekonomis lebih tinggi dari pada hanya dikonsumsi sebagai buah dan sayuran biasa. 
2. Pengetahuan dan keterampilan mengolah pupuk kandang menjadi pupuk fermentasi yang sangat bermanfaat untuk mengembalikan kesuburan tanah perkebunan masyarakat desa Paterongan sebagai solusi alternatif di saat pupuk mulai langka.

3. Pengetahuan dan keterampilan menanam porang sebagai solusi prospektif bagi pemanfaatan lahan-lahan nganggur, dimana permintaan porang saat ini meningkat dengan harga yang menjanjikan.

4. Wawasan tentang pentingnya pengembangan pemasaran dengan menjalin jejaring pemasaran yang sesuai dengan prinsip-prinsip marketing dengan mengimplementasikan manajemen bauran pemasaran.

5. Wawasan tentang pentingnya hak paten untuk melindungi produkproduk yang ada di desa Paterongan dari pengakuan pihak lain. Dengan hak paten, maka warga desa Paterongan akan dapat meningkatkan kerja sama ekonomis dengan pihak-pihak lain tanpa khawatir disalahgunakan hak produknya. 


\section{DAFTAR PUSTAKA}

Arsyad, Lincolin. 2006. Ekonomi Pembangunan, Edisi ke-5. Yogyakarta: STIE YPKN.

Basrowi. 2006. Pengantar Sosiologi. Bogor: Ghalia Indonesia.

Damsar. 2010. Sosiologi Ekonomi. Jakarta: PT Raja Grafindo Persada.

Sunyoto, Usman, dkk,. 2010. Pembangunan dan pemberdayaan Masyarakat. Jakarta: Pustaka Pelajar.

Buku Pedoman KKN Tahun 2020, Bangkalan: STAI Darul Hikmah. 